\title{
Unlike Morphine, Long-Term Exposure to Analgesic Mitragynine, 7-Hydroxymitragynine, Paynantheine, and Speciociliatine Alkaloids Does Not Contribute to Antinociceptive Tolerance of $\mu$-Opioid Receptors
}

Fatemeh Elahian

Shahrekord University of Medical Science

\section{Sorour Zahedian}

Shahrekord University of Medical Science

Mohsen Safaei

Shahrekord University of Medical Science

\section{Elham Pahlevani-Gazi}

Shahrekord University of Medical Science

Seyed Abbas Mirzaei ( $\nabla$ dr_amirzaei@yahoo.com )

Shahrekord University of Medical Science https://orcid.org/0000-0003-0307-3750

\section{Research}

Keywords: Alkaloid, Antigenotoxicity, Antioxidant, $\beta$-Arrestin-2, ERK1/2, $\mu$-Opioid receptor tolerance, Phosphorylated ERK1/2, Western blot

Posted Date: July 6th, 2020

DOI: https://doi.org/10.21203/rs.3.rs-39727/v1

License: (c) (i) This work is licensed under a Creative Commons Attribution 4.0 International License. Read Full License 


\section{Abstract}

Background: Opioids are the most well known antinociceptive alkaloids all over the world, but tolerance and physical dependence are their dominant concerns in clinical applications. In contrast, monoterpene alkaloids are newly considered for their roles in pain management.

Methods: In this regard, the clinical safety of mitragynine, 7-hydroxymitragynine, speciociliatine, and paynantheine was determined by cytotoxicity, antioxidant, and antigenotoxicity assays. In parallel alkaloids were studied on $\beta$ arrestin-2, ERK1/2, and p-ERK1/2 transcription and translation levels during three days on SH-SY5Y cells.

Results: Results confirmed alkaloid- and concentration- dependency of the cytotoxicity, antigenotoxicity, and antioxidant activity. Although morphine was recorded as the safest alkaloid here, speciociliatine and mitragynine represented around 1200- and 20- fold higher DNA protection capacity than morphine, respectively. Monoterpene alkaloids transiently made the transcript ocean turbulent, but western blot analyses have proved significant downregulation of targeted proteins in SH-SY5Y cells during the experiment days.

Conclusions: Data indicated that monoterpene alkaloid derivatives are putative analgesic agents that do not stimulate opioid receptor tolerance and suggesting that patients may benefit from their antinociceptive activities without physical dependence or tolerance concerns in future clinics.

\section{Background}

The kratom tree is a group of evergreen plants that belongs to the Mitragyna genus of the Rubiaceae family. Coffee and garden plants are recognized as other members of this family. Mitragyna speciosa is among the most important species of kratom from the medical perspectives, which is native to Thailand and its diverse neighboring countries in Southeast Asia. For many centuries, Asian people used to ingest the crude plant leaves or use of steeped or brewed from the leaves as psychoactive teas. The major causes for kratom consumption include enhancing sexual efficiency and stability, social and recreational uses for the feeling of happiness and satisfaction, therapeutic goals as pain relievers, and even though the treatment of fever, diarrhea, hypertension and diabetes [12]. Until now, more than 40 alkaloids have been recognized in Mitragyna speciosa. Mitragynine has been uniquely identified as the primary alkaloid constituent, up to $66 \%$ by mass of raw alkaloid extracts. Other important constituents are paynantheine, speciogynine, 7-hydroxymitragynine, and speciociliatine representing $9 \%, 7 \%, 2 \%$, and $1 \%$ of total alkaloid mass, respectively [3-5].

Opium and opioid receptor agonists play a crucial role in pain management. However, important side effects escalate rapidly; for instance, the therapeutic effectiveness of these analgesics plunges very soon, and on the other hand, drug tolerance against their analgesic effects and drug dependence quickly increases. $\mu$-receptor, a member of the G-protein families, is reported as the most critical receptor involving in these features. Recent studies have investigated the pathways correlated with tolerance mechanisms in these receptors, especially in the face of morphine. Activation of $\beta$-arrestin-2, ERK1/2, and phosphorylated counterpart of ERK1/2 proteins was proved to be the most signaling pathways leading to $\mu$-receptor downregulation and finally, drug dependence and antinociceptive tolerance [6-8].

Finding novel alkaloids that does not down regulate opioid receptors is one of the major challenges in medicine. Mitragynine demonstrated a high affinity to $\mu$-opioid receptors. This alkaloid is reported to mediate high levels of analgesia and satisfaction. The antinociceptive activity of mitragynine has been proven to be mediated through 
supraspinal $\mu$ - and $\delta$-opioid receptors. Therefore, this alkaloid is well known as an analgesic agent [9-10]. In terms of analgesic activity, Mitragyna alkaloids were found to be extremely efficient. As illustration mitragynine and 7hydroxymitragynine were reported to have fifteen-fold and fourfold more effective than morphine in a concentration-dependent manner; consequently, such alkaloids can be applied as an opium replacement or to reduce opium addiction, diminishing the pain from withdrawal symptoms [11-12].

The present research examines the toxicity of morphine, mitragynine, 7-hydroxymitragynine, speciociliatine, and paynantheine regarding their antioxidant and antigenotoxic properties as well as investigation of the alkaloids effect on $\beta$-arrestin-2 and ERK1/2 proteins, which play key roles in the tolerance level of the opioid receptors. Since there are no enough documents that confirm the usage of Mitragyna speciosa for clinical implications; therefore, it is necessary to identify the characteristics and mechanism of actions associated with these compounds.

\section{Materials And Methods}

\section{Chemicals}

Mitragynine, 7-hydroxymitragynine, speciociliatine, and paynantheine were purchased from ChromaDex (California, US). RNA extraction, cDNA synthesis, and real-time PCR kits were provided from Qiagen (Hilden, Germany). HRPconjugated anti-mouse secondary antibody and mouse primary antibodies against $\beta$-arrestin-2, ERK1/2, p-ERK1/2, and $\beta$-Actin were obtained from Santa Cruz Biotechnology (California, US). Cell culture media and their supplements were acquired from Gibco (Grand Island, NY, USA). Antioxidation and antigenotoxicity evaluating reagents including DPPH, BHT, linoleic acid, $\beta$-carotene, ascorbic acid, agarose as well as all other chemicals and solvents in this study were supplied from Sigma-Aldrich (Sigma-Aldrich, Deisenhofen, Germany). Morphine and all other reagents were obtained from commercial resources in Iran.

\section{Cell culture and cellular growth kinetic}

SH-SY5Y (CRL-2266, a neuroblastoma cell line, isolated from a bone marrow biopsy) cell line was generously gifted from Professor Mohammad Saeid Jami (Shahrekord University of Medical Sciences). Cells were cultured in DMEM/F12 medium containing 10 \% (v/v) FBS, $100 \mathrm{IU} / \mathrm{ml}$ penicillin, 2 mM L-glutamine, and 100 mg/ml streptomycin in a humidified $\mathrm{CO}_{2}$ incubator at $37^{\circ} \mathrm{C}$. Cellular proliferation was monitored during an 8-day incubation. Initially, cells were cultured into 96-well plates at a density of 8000 cells/well. Cells in the wells were counted daily using MTT assay. A standard mathematical model was fitted to the point. The maximum specific growth rate $\left(\mu_{\max }\right)$ was illustrated as the slope of the line depicted on natural logarithms of the growth (dependent variant) versus the time intervals (independent variant). Data was represented as the mean values $\pm \mathrm{SE}$ of three independent experiments [13].

\section{In-vitro analyses of cytotoxicity}

Briefly, SH-SY5Y cells were sub-cultured at a density of 15000 cells/well in 96-well plates and cultivated $24 \mathrm{~h}$ at 37 ${ }^{\circ} \mathrm{C}$. Then, the cells were exposed to serial dilutions $(0-300 \mu \mathrm{M})$ of morphine, mitragynine, 7-hydroxymitragynine, speciociliatine, or paynantheine. Eventually, cell survival was assessed after a 5-day incubation applying MTT assay. The optical density was read on a plate reader at $570 \mathrm{~nm}$. IC $\mathrm{C}_{50}$ values were expressed as the concentration of the agents, reducing cell growth by $50 \%$; also, $I_{10}$ values were determined as the concentration of a compound decreased cell growth by $10 \%$. The cytotoxic values were determined by the best regression plot of the percentage viability against any compound concentrations [14]. 


\section{Antioxidant properties of the alkaloids}

The antioxidation properties of the alkaloids have been evaluated either using DPPH or $\beta$-carotene/linoleic method. DPPH method is based on the disappearance of the DPPH free radicals and consequently reduction of the absorption at $517 \mathrm{~nm}$. Two milliliter of a fresh DPPH stock was added to various concentrations of each alkaloid $(0-400 \mu \mathrm{M})$ and placed in the dark for $30 \mathrm{~min}$. Scavenging capacity percentage was determined by [(control absorbance - sample absorbance) $\times 100$ / control absorbance]

equation. Bleaching assay was conducted using an emulsion composed of $\beta$-carotene and linoleic acid. Briefly, 1 mg yellow $\beta$-carotene pigment, $45 \mu \mathrm{l}$ of 9 -cis-12-cis-linoleic acid (density= $0.902 \mathrm{~g} / \mathrm{ml}$ ), and $200 \mu \mathrm{l}$ of Tween-20 (density $=1.095 \mathrm{~g} / \mathrm{ml}$ ) were homogenized in $2 \mathrm{ml}$ of chloroform. Then chloroform was rotary evaporated at $40{ }^{\circ} \mathrm{C}$ for $30 \mathrm{~min}$ and then $100 \mathrm{ml}$ of oxygenated deionized water was mixed with vigorous shaking to form a homogenized stable nanoemulsion. Then, $2.5 \mathrm{ml}$ of the emulsion was added to $350 \mu \mathrm{l}$ of various alkaloid concentrations $(0-400 \mu \mathrm{M})$. The mixtures left at $50^{\circ} \mathrm{C}$ in the light for $2 \mathrm{~h}$ and the optical density was recorded at $470 \mathrm{~nm}$. Bleaching inhibition capacity percentage was calculated from [(sample absorbance at time 0 - sample absorbance after $2 \mathrm{~h}$ ) $\times 100$ / (control absorbance at time 0 - control absorbance after $2 \mathrm{~h}$ )]equation. Controls contained all reagents except the antioxidant factors. The scavenging capacity-50 $\left(\mathrm{SC}_{50}\right)$ or bleaching inhibitory capacity-50 $\left(\mathrm{BIC}_{50}\right)$ is an alkaloid concentration required for scavenge $50 \%$ of DPPH radicals or protects half percentage of $\beta$-carotene molecules from bleaching, respectively. They were calculated from the calibration curve determined by the regression line from the scavenging capacity or bleaching inhibition percentages versus alkaloid concentrations. Butylated hydroxytoluene (BHT, 0-100 $\mu \mathrm{M})$ was used as standard antioxidant agents [15-16].

\section{Antigenotoxic activity of alkaloids using COMET assay}

The induced DNA damage by the alkaloids was evaluated on SH-SY5Y cells by the COMET assay conducted under alkaline conditions. A serial dilution of each alkaloid (final concentrations of 0 to $600 \mu \mathrm{M}$ ) was supplemented with $120 \mu \mathrm{M} \mathrm{H}_{2} \mathrm{O}_{2}$ solution and stored for $5 \mathrm{~min}$ at ambient temperature. Then, 10000 cells were transferred to all dilutions, and the suspension was kept for 30 min at $4{ }^{\circ} \mathrm{C}$. Next, cells were harvested and sandwiched on a slide between two layers of $0.75 \% \mathrm{w} / \mathrm{v}$ low-melting point agarose. The slides were submerged in cold lysis buffer for at least $4 \mathrm{~h}$. The lysis solution was composed of $2.25 \mathrm{M}$ sodium chloride, $90 \mathrm{mM}$ ethylenediaminetetraacetic acid, $9 \mathrm{mM}$ Tris, and $\mathrm{pH}$ was adjusted to 10 . The lysis buffer was freshly supplemented with $0.7 \% \mathrm{w} / \mathrm{v}$ sodium hydroxide, $10 \% \mathrm{v} / \mathrm{v}$ dimethyl sulfoxide, $1 \% \mathrm{v} / \mathrm{v}$ Triton X-100 before use. Then, the cells were subjected to a constant electric field in a horizontal electrophoresis chamber (300 mA for $40 \mathrm{~min}$ at $4{ }^{\circ} \mathrm{C}$ ). The Chamber contained freshly prepared alkaline buffer (300 mM Sodium hydroxide; 1 mM ethylenediaminetetraacetic acid; $\mathrm{pH} \sim 13$ ). The slides were then neutralized using a neutralizing buffer (0.4 M Tris; $\mathrm{pH}=7.5)$. Finally, DNA was stained with $20 \mu$ l ethidium bromide $(2 \mu \mathrm{g} / \mathrm{ml})$ and pictured using a fluorescent microscope (BX51; Tokyo, Japan). The DNA damage was analyzed via Open-Comet software and Cells were determined undamaged to maximally damaged, according to tail DNA intensity [Tail DNA×100 $\div$ (Head DNA + Tail DNA)], for each alkaloid concentrations. The COMET-inhibitory capacity-50 $\left(\mathrm{CIC}_{50}\right)$ defined as the concentration of the alkaloid that diminishes the tail DNA percent to $50 \%$ against damage induced by $\mathrm{H}_{2} \mathrm{O}_{2}$ and calculated from the calibration curve determined by the best regression line between tail DNA percentage and alkaloid concentrations. BHT (0 to $1000 \mu \mathrm{M})$ was used as a standard antigenotoxic agent [17-18].

\section{Quantitative analyses of the transcripts}


SH-SY5Y cells were exposed to $\mathrm{IC}_{10}$ concentration of each alkaloid for 24,48 , and $72 \mathrm{~h}$. RNA was extracted from the cells by the RNeasy mini kit, and cDNA was constructed with QuantiTect Reverse Transcription Kit from $1 \mu \mathrm{g}$ of total RNA according to the company instructions using random hexamer as priming sequences. ARRB2, MAPK1, and MAPK3 transcripts were relatively quantified with the QuantiTect SYBR Green kit on a Rotor-Gene Q instrument (Qiagen, Hilden, Germany) according to the Pfaffl method. Three primer pairs were designed using Gene Runner Ver. 3.05 software and the sequences were validated using the Primer-BLAST tool available on the NCBI website. Amplification was optimized under the following conditions: a pre-denaturation step at $95^{\circ} \mathrm{C}$ for 10 min; 45 cycles for amplification step $\left(15 \mathrm{~s}\right.$ denaturation at $95^{\circ} \mathrm{C}, 20 \mathrm{~s}$ annealing temperature at $60^{\circ} \mathrm{C}$, and $20 \mathrm{~s}$ extension at $72{ }^{\circ} \mathrm{C}$ ), and a standard melting analysis carried out after the amplification step $\left(1{ }^{\circ} \mathrm{C} /\right.$ step between $\left.60-90{ }^{\circ} \mathrm{C}\right)$. The efficiency for each primer pair was determined with a serial dilution of cDNA. The transcript level was normalized to $\beta$-actin as the internal reference gene [19-20].

\section{Quantification of protein in the signaling pathway}

Western blotting was used for semi-quantification of the targeted proteins. In brief, after treatment time, total proteins were extracted using lysis solution (7 M urea, $2 \mathrm{M}$ thiourea, $10 \mathrm{mM} \mathrm{PMSF,} \mathrm{1 \%} \mathrm{w/v} \mathrm{DTT,} \mathrm{pH} \mathrm{3-10),} \mathrm{The}$ protein concentration was determined using the commercial Bradford protein assay kit. Human serum albumin was used as a standard curve for protein quantification. $50 \mu \mathrm{g}$ of the total protein was electrophoresed on $12 \%$ polyacrylamide SDS-PAGE according to Laemmli method on a discontinuous buffer system. Then, protein bands were blotted onto nitrocellulose membranes via a semi-dry Trans-Blot instrument (Bio-Rad, Richmond, CA) under constant current of $3 \mathrm{~mA} / \mathrm{cm}^{2}$ for $60 \mathrm{~min}$. The efficiency of protein transfer was monitored using Ponceau-S staining. Then, the unspecific membrane surface was blocked with $5 \%$ BSA for $1 \mathrm{~h}$, and the blot was treated with $1: 500 \mathrm{v} / \mathrm{v}$ mouse monoclonal IgG antibody against $\beta$-actin, $\beta$-arrestin-2, ERK1/2, or $\mathrm{p}$-ERK1/2. Secondary mouse IgG kappa binding protein conjugated to horseradish peroxidase ( $\mathrm{m}-\mathrm{lgGK}-\mathrm{HRP}, 1: 5000 \mathrm{v} / \mathrm{v})$ along with luminol was used for band visualization. The chemiluminescence wave was recorded with a Li-Cor scanner (Lincoln, NE, USA). The density of each protein band was quantified and normalized with $\beta$-actin results [19, 21].

\section{Statistical analyses}

Three independent runs were carried out in adequate replicates for any analytical experiments. Data analysis was assessed with SPSS-22 statistical software. Stars (Ü), (ÜÜ), and (ÜÜÜ) represent the mean differences between normalized treated and normalized untreated group levels as $\mathrm{P}<0.05, \mathrm{P}<0.01$, and $\mathrm{P}<0.001$ using one-way ANOVA, respectively.

\section{Results}

\section{Growth kinetics and cytotoxicity analyses}

SH-SY5Y cells were monitored for growth properties during five days with MTT colorimetric assays. The growth kinetics represented that the cells grew in an exponential growth pattern. The $\operatorname{Ln}(x)=\operatorname{Ln}\left(x_{0}\right)+0.0133 \times$ t equation represents the growth pattern during the logarithmic phase in the DMEM/F12 medium at optimal conditions without any drug treatments. This condition provided a maximum growth rate and a doubling time equal to $0.0133 \mathrm{~h}^{-1}$ and $52.12 \mathrm{~h}$, respectively. These cells normally reached the plateau phase after two weeks (Supplementary Fig S1). To investigate the effects of alkaloid compounds, including mitragynine, paynantheine, speciociliatine, and 7-hydroxymitragynine on cell survival, the cells were treated with increasing doses of each 
compound. A dose-response curve was fitted to our data, and the $\mathrm{IC}_{10}$ and $\mathrm{IC}_{50}$ values were determined by MTT viability assays after five days of treatment (Supplementary Fig S2 and S3). Initial observation revealed alkaloid derivatives inhibited cell growth dose-, and time-dependent. The most and the least cytotoxic alkaloids on the SHSY5Y cell line were 7-hydroxymitragynine $(\mathrm{P}<0.001)$ and morphine $(\mathrm{P}<0.001)$, with $\mathrm{IC}_{50}$ values of approximately $29 \mu \mathrm{M}$ and $1262 \mu \mathrm{M}$, respectively (Table 1 and Supplementary Table S1).

Table 1

Safety analyses of alkaloids. Safety of morphine, mitragynine, 7-hydroxymitragynine, paynantheine, and speciociliatine was measured regarding cytotoxicity $\left(\mathrm{IC}_{50}\right.$ and $\left.\mathrm{IC}_{10}\right)$, radical scavenging activity $\left(\mathrm{SC}_{50}\right)$, bleaching inhibitory capacity $\left(\mathrm{BIC}_{50}\right)$, and antigenotoxic concentration $\left(\mathrm{CIC}_{50}\right)$. Cellular experiments were conducted on $\mathrm{SH}$ SY5Y, and all data were expressed as the mean \pm standard deviation. Values in the same row with common letters represent statistical insignificance $(P>0.05)$ using ANOVA analysis.

\begin{tabular}{|c|c|c|c|c|c|c|}
\hline $\begin{array}{l}\text { Sample } \\
\text { Concentration } \\
(\mu \mathrm{M})\end{array}$ & $\begin{array}{l}\text { Butylated } \\
\text { hydroxytoluene }\end{array}$ & Morphine & Mitragynine & $\begin{array}{l}\text { 7-Hydroxy } \\
\text { mitragynine }\end{array}$ & Paynantheine & Speciociliatine \\
\hline $\begin{array}{l}\mathrm{IC}_{10} \\
\text { cytotoxicity } \\
\text { potency on } \\
\text { SH-SY5Y } \\
\text { cells }\end{array}$ & $105.77 \pm 8.20^{c}$ & $\begin{array}{l}113.03 \pm \\
5.8^{c}\end{array}$ & $\begin{array}{l}31.28 \pm \\
5.95^{b}\end{array}$ & $\begin{array}{l}7.49 \pm 1.02 \\
a\end{array}$ & $36.10 \pm 4.83^{b}$ & $36.33 \pm 3.12^{b}$ \\
\hline $\begin{array}{l}\mathrm{IC}_{50} \\
\text { cytotoxicity } \\
\text { potency on } \\
\text { SH-SY5Y } \\
\text { cells }\end{array}$ & $\begin{array}{l}1362.05 \pm \\
60.14^{c}\end{array}$ & $\begin{array}{l}1262.88 \\
\pm 83.13^{c}\end{array}$ & $\begin{array}{l}63.69 \pm \\
5.38^{b}\end{array}$ & $\begin{array}{l}29.53 \pm \\
4.82^{a}\end{array}$ & $68.13 \pm 3.93^{b}$ & $68.63 \pm 5.52^{b}$ \\
\hline $\begin{array}{l}\text { Radical } \\
\text { scavenging } \\
\text { activity } \\
\left(\mathrm{SC}_{50}\right)\end{array}$ & $31.77 \pm 4.19^{a}$ & $\begin{array}{l}64.33 \pm \\
7.50^{b}\end{array}$ & $114 \pm 9.54^{c}$ & $\begin{array}{l}324 \pm 16.16 \\
e\end{array}$ & $139 \pm 7.94^{c}$ & $290 \pm 14.52^{d}$ \\
\hline $\begin{array}{l}\text { Bleaching } \\
\text { inhibitory } \\
\text { capacity } \\
\left(\mathrm{BIC}_{50}\right)\end{array}$ & $9.08 \pm 0.95^{a}$ & $\begin{array}{l}314 \pm \\
9.00^{c}\end{array}$ & $134 \pm 5.57^{b}$ & $304 \pm 6.03^{c}$ & $361 \pm 9.00^{d}$ & $386 \pm 9.71^{e}$ \\
\hline $\begin{array}{l}\text { Comet } \\
\text { inhibitory } \\
\text { concentration } \\
\left(\mathrm{ClC}_{50}\right)\end{array}$ & $\begin{array}{l}544.59 \pm 63.74 \\
\text { d }\end{array}$ & $\begin{array}{l}203 \pm \\
8.08^{c}\end{array}$ & $\begin{array}{l}9.76 \pm 2.21 \\
a\end{array}$ & $\begin{array}{l}164.67 \pm \\
10.69^{b}\end{array}$ & $e^{1270 \pm 20.60}$ & $0.17 \pm 0.07^{a}$ \\
\hline
\end{tabular}

\section{Antioxidant And Antigenotoxicity Effectiveness Of The Alkaloids}

The alkaloids represented significant dose-dependent antioxidant and antigenotoxic activities. Table 1 and Supplementary Table S1 confirmed that alkaloid properties are most likely type-specific. For instance, mitragynine represented the highest free radical scavenging property around $114 \mu \mathrm{M}$, while 7-hydroxymitragynine exhibited the least activity $(324 \mu \mathrm{M})$ in this experiment (Supplementary Figure S4). On the other hand, oxidation and removal of the hydrogen atom from bis-allylic methylene moieties of linoleic acid produce free radicals that can lead to discoloration of $\beta$-carotene. Here mitragynine demonstrated the best inhibitory performance with a $\mathrm{BIC}_{50}$ value of $134 \mu \mathrm{M}$ while speciociliatine had the weakest $\left(\mathrm{BIC}_{50}=386 \mu \mathrm{M}\right)$ performance (Supplementary Figure S5). In 
contrast, data in Supplementary Figure S6 and S7 illustrated that the pretreated SH-SY5Y cells with alkaloid compounds had a significant reduction in the DNA damage. Speciociliatine and mitragynine represented approximately three thousand and sixty times stronger DNA protection characteristics than BHT as a standard antigenotoxic agent, respectively (Fig. 1).

\section{Alkaloid Effects On The Transcript Levels}

ARRB2, MAPK1, and MAPK3 transcripts were relatively quantified after SH-SY5Y cell exposure to IC 10 doses of morphine, mitragynine, paynantheine, and 7-hydroxymitragynine. The primer sets were successfully designed using Gene Runner software version 3.05 and then controlled on the Primer-BLAST database on NCBI (Supplementary Table S2). The amplification conditions were optimized to achieve the best amplification efficiency ( $E \geq 1.9$ and Rsquared $\geq 0.98$ ) based on the standard Pfaffl method (Supplementary figure S8). Figure 2 indicated that morphine elevated all transcripts, approximately three-fold, after $48 \mathrm{~h}(\mathrm{P}<0.05)$ and then returned to the basal conditions. On the other hand, the ARRB2 transcript level dropped down after $72 \mathrm{~h}$ of SH-SY5Y exposure to 7-hydroxymitragynine $(P<0.001)$. Paynantheine represented a significant suppressing pattern most of the times on the genes. All other treatments and exposure times did not reflect considerable outcomes on the transcript levels $(P>0.05)$.

\section{$\beta$-Arrestin-2, ERK1/2, and p-ERK1/2 translation levels}

The protein level of $\beta$-arrestin-2, ERK1/2, and p-ERK1/2 was determined using western blotting (Fig. 3). Interestingly morphine increased all targeted protein levels after 24,48 , and $72 \mathrm{~h}$. On the other hand, results revealed the downregulation of $\beta$-arrestin- 2 in the cells after all treatments and exposure periods except after $48 \mathrm{~h}$ exposure with 7hydroxymitragynine and $24 \mathrm{~h}$ with paynantheine. Although mitragynine and 7-hydroxymitragynine slightly increased p-ERK1/2 levels, p-ERK1/2 translation level decreased after 24 and $72 \mathrm{~h}$ treatment with paynantheine. ERK1/2 almost down regulated after treatment with the targeted alkaloids. Protein down-regulation is the major phenomenon observed in the mitragynine, 7-hydroxymitragynine, and paynantheine treatment, especially at the latter treatment times (Supplementary figure S9 and S10)

\section{Discussion}

Pharmacological evidence chiefly proved the anaesthetic, antitussive, stimulant, antinociceptive, analgesic, narcotic, anti-inflammatory, antidepressant, antioxidant, and antibacterial activities of Mitragyna speciosa alkaloids $[9,22]$. Cytotoxicity values are crucial parts of modern pharmaceuticals development. Table 1 represents cytotoxicity of the monoterpene indoles along with the isoquinoline alkaloid, morphine. Morphine was generally regarded as less toxic agent among all alkaloids in the Table. Even though 7-hydroxymitragynine possessed a significant cytotoxic activity against SH-SY5Y cells, other monoterpene alkaloids toxicity varied slightly, and they almost categorized in the same statistical group. Since they share a typical chemical skeleton with different structural conformation or substitution patterns. On the other hand, toxicity is a truly complex phenomenon that is influenced by several factors like cellular penetration, diffusion, distribution, metabolism, innate toxicity of the agent, and target cell specifications [23-24].

It is not surprising that butylated hydroxytoluene, as one of the synthetic phenolic derivatives, has the strongest antioxidant properties compared to other compounds (Table 1). Many studies showed that phenolic and polyphenolic structures are primarily capable of radical scavenging. They carry some hydroxyl moieties on the rings and efficiently donate $\mathrm{H}$-atoms to free radicals and creating relatively less reactive phenoxyl radicals due to 
resonance stabilization of the aromatic ring. This phenomenon interprets the mechanism of DPPH free radical neutralization. On the other hand, quenching of the singlet state of oxygen and converting it into its stable triplet state can exhibit its secondary antioxidant properties. Therefore, they block lipid peroxidation in the $\beta$ carotene/linoleic acid method. Unfortunately, there are always some concerns regarding the use of synthetic phenolic compounds due to their possible carcinogenic potential and developing some other safer agents is crucial [25].

Results in Table 1 reveal morphine and mitragynine have the highest antioxidant activity between the alkaloids. Morphine favors from hydrogen abstraction in the aromatic phenol ring. The free radical in this position is highly stable due to spin contribution and resonance (Supplementary Figure S1). Also, aliphatic hydroxyl, alkyl moieties, aromatic rings, double bonds, and amine groups contribute to antioxidant properties [26-27]. Even though the monoterpene alkaloids do not contain phenolic structure since do not assist in such a potent hydrogen-donating antioxidant pathway; they participate in antioxidation mechanisms through hydroxyl group on indole moiety (7hydroxymitragynine), methoxy group on the aromatic ring, other alkyl groups on the aliphatic ester/ ether parts, or more dominantly $\mathrm{H}$-donation from $\mathrm{N}-\mathrm{H}$ on the indole ring (except 7-hydroxymitragynine) [28].

Finally, hydroxyl radical scavenging effects of the monoterpene indole structures could explain the potent genoprotective activity of mitragynine and speciociliatine against $\mathrm{H}_{2} \mathrm{O}_{2}$-induced oxidative DNA damage. Literature also suggested that monoterpenes promptly increase Nrf2 accumulation in the nucleus; therefore, they have a positive influence on antioxidant enzymes and activation of DNA repair mechanisms. Additionally, the lipophilic structures of these two diastereomers allow easier distribution into the cells and hence more DNA protective effects in comparison with more hydrophilic phenolic structures [29]. Generally, antioxidant and antigenotoxicity effects of the alkaloids are highly type-specific and dose-dependent and many results could not be interpreted with the molecular structure, presence of heteroatoms, or lipophilicity/ hydrophilicity ratio.

Although opium structures play an essential role in pain management, tolerance and physical dependence are among the main problematic issues in clinical applications. Therefore, scientists focused on $\mu$-receptor agonists extension to design and synthesize vigorous antinociceptive factors that are lacking these disadvantageous side effects. The $\mu$-opioid receptors belong to the $\mathrm{G}$ protein-coupled membrane receptor (GPCR) family. In the literature, $\beta$-arrestin-2 is considered the most critical protein in the regulation and antinociceptive tolerance of opioid receptors. ARRB2 gene (coding for $\beta$-arrestin-2) is highly expressed in the central and peripheral nervous systems. $\beta$ Arrestin-2 was proved to have a strong binding capacity with the phosphorylated form of GPCR. This interaction prevents normal interactions between the receptor and $\mathrm{G}$ proteins. Therefore, downstream signaling is also blocked even in the presence of the receptor agonists. Moreover, $\beta$-arrestin- 2 initiates clathrin-dependent endocytosis and reduces $\mu$-opioid receptors on the cell surface, prominently. $\beta$-Arrestin- 2 knockdown was responsible for antinociceptive intolerance in animal models [30-31].

Nevertheless, some investigations revealed documents that tolerance and endocytosis of opioid receptors happened during morphine treatment via activation of the ERK1/2 cascade (encoded protein by MAPK1/3 gene). In this regard, MEK1/2 catalyze human ERK1/2 phosphorylation at Tyr ${ }^{204 / 187}$ and Thr ${ }^{202 / 185}$. Both tyrosine and threonine phosphorylation is required for enzyme activation. In contrast, p-ERK1/2 are activated serine/threonine kinases that trigger primary events leading to a variety of cellular processes from survival and differentiation of the cells to phosphorylation and tolerance of the $\mu$-opioid receptors [29, 32-33]. 
Many scientists reported the upregulation of $\beta$-arrestin-2 and ERK1/2 after long-term morphine treatment, both invivo and in-vitro. In addition, the phosphorylated and active form of ERK1/2 (p-ERK1/2) increased significantly after chronic morphine administration [32,34-35]. These findings are coincident with the present results. Morphine increased all three targeted proteins during $72 \mathrm{~h}$ exposure and most of them are significant, especially on final days (Fig. 3 and supplementary figure S10). Real-time results are almost consistent with the western blot experiments (Fig. 2 and Fig. 3). Although in some cases transcription level returned to the usual steady-state after three days, translation continued to remain higher (in morphine treatment) or lower (in other treatments). Literatures have rationalized such incompatible fluctuations to higher protein half-life and more stable post-transcriptional changes.

\section{Conclusion}

Previous reports have introduced varieties of distinct mechanisms mediating chronic and acute $\mu$-opioid receptor tolerance in the central nervous system, even in the presence of opioid analogues. GPCR phosphorylation and clathrin-dependent endocytosis are among the prominent reasons for the tolerance to antinociceptive effects of opioid compounds. $\beta$-Arrestin-2, ERK1/2, and p-ERK1/2 play essential roles in these mechanisms. It is necessary to find and synthesize novel drugs that minimize the side effects, especially the tolerance towards these drugs. In general, the examined monoterpene alkaloids represented considerable radical scavenging, lipid peroxidation, and hydroxyl radical scavenging properties. Even though the up-regulation of $\beta$-arrestin-2, ERK1/2, and p-ERK1/2 proteins is revealed the main mechanism for the receptor tolerance in the presence of morphine, it should be highlighted that long-term treatment with the monoterpene alkaloid mostly down-regulated these proteins. These properties would make such alkaloids suitable candidates that should be quickly moved to clinical applications.

\section{Abbreviations}

\section{ERK1/2}

Extracellular signal-regulated protein kinase; SH-SY5Y:CRL-2266, a neuroblastoma cell line, isolated from a bone marrow biopsy; MTT:3-(4,5-dimethylthiazol-2-yl)-2,5-diphenyltetrazolium bromide; FBS:Fetal bovine serum; DPPH:2,2-diphenyl-1-picrylhydrazyl; BHT:Butylated hydroxytoluene; SC50:scavenging capacity-50; BIC50:bleaching inhibitory capacity-50; CIC50:COMET-inhibitory capacity-50; GPCR:G protein-coupled membrane receptor.

\section{Declarations}

Ethical Approval and Consent to Participate: This article does not contain any studies with human participants or animals performed by any of the authors.

Consent for publication: All listed authors have actively participated in the study and have read and approved the submitted manuscript.

Availability of supporting data: The datasets generated and/or analyzed during the current study are available on request from the corresponding author.

Competing Interests: The authors declare that they have no competing interests.

Funding: We would like to grateful Shahrekord University of Medical Sciences for the financial support (grant number: SKUMS-2367) and Iran National Science Foundation (grant number INSF-98017765). 


\section{Authors' contributions}

S.A. Mirzaei and F. Elahian coordinated the study, designed the experiments, and wrote the manuscript. M. Safaei (Ph.D. student), S. Zahedian (M.Sc. student), and E. Pahlevani-Gazi (M.Sc. student) were the students who performed the experiments and participated in the data analyses and intellectual discussions of the data and manuscript writing as parts of their theses. All authors read and approved the final manuscript.

Acknowledgements: We would like to thank Professor Professor M. Ghatrehsamani (Department of Medical Immunology) for his valuable feedback and suggestions.

\section{Author information:}

${ }^{1}$ Department of Medical Biotechnology, School of Advanced Technologies, Shahrekord University of Medical Sciences, Shahrekord, Iran. ${ }^{2}$ Cellular and Molecular Research Center, Basic Health Sciences Institute, Shahrekord University of Medical Sciences, Shahrekord, Iran.

\section{References}

1. Prozialeck WC, Jivan JK, Andurkar SV. Pharmacology of kratom: an emerging botanical agent with stimulant, analgesic and opioid-like effects. J Am Osteopath Assoc. 2012;112:792-9.

2. Cinosi E, Martinotti G, Simonato P, Singh D, Demetrovics Z, Roman-Urrestarazu A, Bersani FS, Vicknasingam B, Piazzon G, Li J-H: Following "the roots" of Kratom (Mitragyna speciosa): the evolution of an enhancer from a traditional use to increase work and productivity in Southeast Asia to a recreational psychoactive drug in western countries. Biomed Res Int 2015, 2015.

3. Kruegel AC, Grundmann O. The medicinal chemistry and neuropharmacology of kratom: A preliminary discussion of a promising medicinal plant and analysis of its potential for abuse. Neuropharmacology. 2018;134:108-20.

4. Arndt T, Claussen U, Güssregen B, Schröfel S, Stürzer B, Werle A, Wolf G. Kratom alkaloids and Odesmethyltramadol in urine of a "Krypton" herbal mixture consumer. Forensic Sci Int. 2011;208:47-52.

5. Feng L-Y, Battulga A, Han E, Chung H, Li J-H. New psychoactive substances of natural origin: a brief review. J Food Drug Anal. 2017;25:461-71.

6. Kruegel AC, Gassaway MM, Kapoor A, Váradi A, Majumdar S, Filizola M, Javitch JA, Sames D. Synthetic and receptor signaling explorations of the Mitragyna alkaloids: mitragynine as an atypical molecular framework for opioid receptor modulators. J Am Chem Soc. 2016;138:6754-64.

7. Pasternak GW, Pan Y-X. Mu opioids and their receptors: evolution of a concept. Pharmacological reviews. 2013;65:1257-317.

8. Stevenson GW, Luginbuhl A, Dunbar C, LaVigne J, Dutra J, Atherton P, Bell B, Cone K, Giuvelis D, Polt R. The mixed-action delta/mu opioid agonist MMP-2200 does not produce conditioned place preference but does maintain drug self-administration in rats, and induces in vitro markers of tolerance and dependence. Pharmacology Biochemistry Behavior. 2015;132:49-55.

9. Hassan Z, Muzaimi M, Navaratnam V, Yusoff NH, Suhaimi FW, Vadivelu R, Vicknasingam BK, Amato D, von Hörsten S, Ismail NI. From Kratom to mitragynine and its derivatives: physiological and behavioural effects related to use, abuse, and addiction. Neuroscience Biobehavioral Reviews. 2013;37:138-51. 
10. Machelska H, Celik M. Advances in achieving opioid analgesia without side effects. Front Pharmacol. 2018;9:1388.

11. Matsumoto K, Horie S, Takayama H, Ishikawa H, Aimi N, Ponglux D, Murayama T, Watanabe K. Antinociception, tolerance and withdrawal symptoms induced by 7-hydroxymitragynine, an alkaloid from the Thai medicinal herb Mitragyna speciosa. Life sciences. 2005;78:2-7.

12. Vicknasingam B, Narayanan S, Beng GT, Mansor SM. The informal use of ketum (Mitragyna speciosa) for opioid withdrawal in the northern states of peninsular Malaysia and implications for drug substitution therapy. Int J Drug Policy. 2010;21:283-8.

13. Carpentieri A, Cozzoli E, Scimeca M, Bonanno E, Sardanelli A, Gambacurta A. Differentiation of human neuroblastoma cells toward the osteogenic lineage by mTOR inhibitor. Cell Death Dis. 2015;6:e1974.

14. Liu W, Geng L, Chen Y. MiR-19b alleviates MPP+-induced neuronal cytotoxicity via targeting the HAPLN4/MAPK pathway in SH-SY5Y cells. RSC Adv. 2018;8:10706-14.

15. do Rosário Martins M, Arantes S, Candeias F, Tinoco MT, Cruz-Morais J. Antioxidant, antimicrobial and toxicological properties of Schinus molle L. essential oils. J Ethnopharmacol. 2014;151:485-92.

16. Demirci B, Koşar M, Demirci F, Dinc M, Başer K. Antimicrobial and antioxidant activities of the essential oil of Chaerophyllum libanoticum Boiss. et Kotschy Food chemistry. 2007;105:1512-7.

17. Zainol M, Stoute J, Almeida GM, Rapp A, Bowman KJ, Jones GD, Ecvag. Introducing a true internal standard for the Comet assay to minimize intra-and inter-experiment variability in measures of DNA damage and repair. Nucleic acids research. 2009;37:e150-0.

18. Casanova NA, Carballo MA. Antigenotoxic activity of watercress extract in an in vitro mammalian system using comet assay. Phytother Res. 2011;25:1743-6.

19. Li P, Cook JA, Gilkeson GS, Luttrell LM, Wang L, Borg KT, Halushka PV, Fan H. Increased expression of betaarrestin 1 and 2 in murine models of rheumatoid arthritis: isoform specific regulation of inflammation. Molecular immunology. 2011;49:64-74.

20. Sereia AL, de Oliveira MT, Baranoski A, Marques LLM, Ribeiro FM, Isolani RG, de Medeiros DC, Chierrito D, Lazarin-Bidóia D, Zielinski AAF. In vitro evaluation of the protective effects of plant extracts against amyloidbeta peptide-induced toxicity in human neuroblastoma SH-SY5Y cells. PloS one. 2019;14:e0212089.

21. Koshimizu T-a, Honda K, Nagaoka-Uozumi S, Ichimura A, Kimura I, Nakaya M, Sakai N, Shibata K, Ushijima K, Fujimura A. Complex formation between the vasopressin $1 \mathrm{~b}$ receptor, $\beta$-arrestin-2, and the $\mu$-opioid receptor underlies morphine tolerance. Nat Neurosci. 2018;21:820-33.

22. Parthasarathy S, Bin Azizi J, Ramanathan S, Ismail S, Sasidharan S, Said MI, Mansor S. Evaluation of antioxidant and antibacterial activities of aqueous, methanolic and alkaloid extracts from Mitragyna speciosa (Rubiaceae family) leaves. Molecules. 2009;14:3964-74.

23. Azizi J, Ismail S, Mordi MN, Ramanathan S, Said MIM, Mansor SM. In vitro and in vivo effects of three different Mitragyna speciosa Korth leaf extracts on phase II drug metabolizing enzymes-glutathione transferases (GSTs). Molecules. 2010;15:432-41.

24. Chen H-M, Yang Y-T, Li H-X, Cao Z-X, Dan X-M, Mei L, Guo D-L, Song C-X, Dai Y, Hu J. Cytotoxic monoterpenoid indole alkaloids isolated from the barks of Voacanga africana Staph. Nat Prod Res. 2016;30:1144-9.

25. Pandey KB, Rizvi SI. Plant polyphenols as dietary antioxidants in human health and disease. Oxid Med Cell Longev. 2009;2:270-8. 
26. Bendary E, Francis R, Ali H, Sarwat M, El Hady S. Antioxidant and structure-activity relationships (SARs) of some phenolic and anilines compounds. Ann Agric Sci. 2013;58:173-81.

27. Borges RS, Vale JK, Pereira GA, Veiga AA, Junior JB, da Silva AB. An antioxidant mechanism of morphine and related derivatives. MED CHEM RES. 2016;25:852-7.

28. Wojtunik-Kulesza KA, Kasprzak K, Oniszczuk T, Oniszczuk A. Natural monoterpenes: Much more than only a scent. Chem Biodivers 2019.

29. Porres-Martínez M, González-Burgos E, Carretero ME, Gómez-Serranillos MP. In vitro neuroprotective potential of the monoterpenes a-pinene and 1, 8-cineole against H2O2-induced oxidative stress in PC12 cells. Z Naturforsch C J Biosci. 2016;71:191-9.

30. Darbari DS, Minniti CP, Rana S, Van Den Anker J. Pharmacogenetics of morphine: Potential implications in sickle cell disease. Am J Hematol. 2008;83:233-6.

31. Hales T: Arresting the development of morphine tolerance and dependence. Oxford University Press; 2011.

32. Bilecki W, Zapart G, Ligęza A, Wawrzczak-Bargiela A, Urbański M, Przewłocki R. Regulation of the extracellular signal-regulated kinases following acute and chronic opioid treatment. Cellular Molecular Life Sciences CMLS. 2005;62:2369-75.

33. Macey TA, Lowe JD, Chavkin C. Mu opioid receptor activation of ERK1/2 is GRK3 and arrestin dependent in striatal neurons. J Biol Chem. 2006;281:34515-24.

34. Muller DL, Unterwald EM. In vivo regulation of extracellular signal-regulated protein kinase (ERK) and protein kinase B (Akt) phosphorylation by acute and chronic morphine. J Pharmacol Exp Ther. 2004;310:774-82.

35. Zamora-Martinez ER, Edwards S. Neuronal extracellular signal-regulated kinase (ERK) activity as marker and mediator of alcohol and opioid dependence. Front Integr Neurosci. 2014;8:24.

\section{Figures}




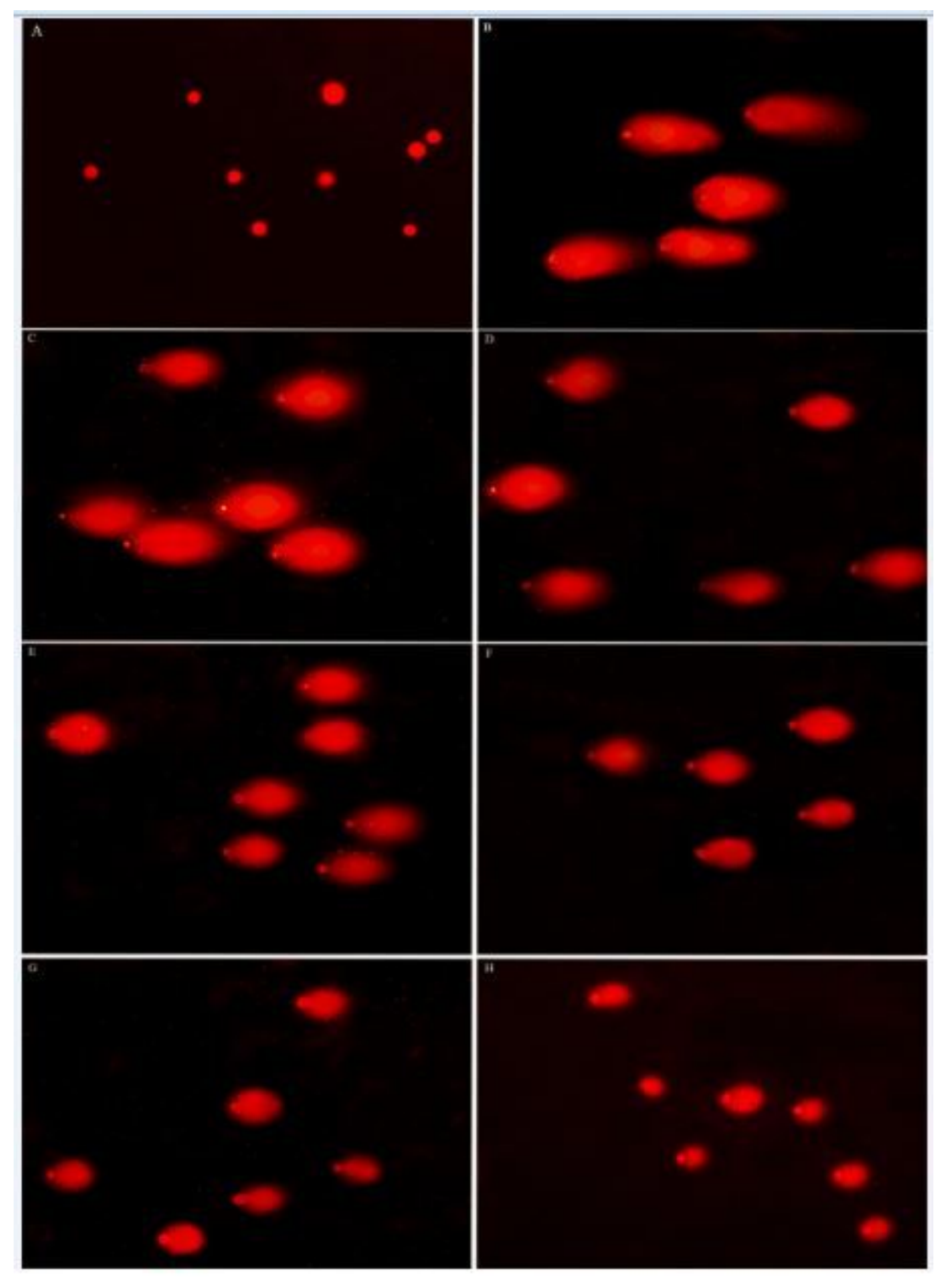

\section{Figure 1}

COMET-images (A) SH-SY5Y cells without any treatment (negative COMET), (B) hydrogen peroxide-treated cells (positive COMET) and ( $\mathrm{C}-\mathrm{H}$ ) serial speciociliatine concentration at 0, 150, 200, 250, 400 and $600 \mu \mathrm{M}$, each supplemented with $120 \mu \mathrm{M} \mathrm{H} 2 \mathrm{O} 2$. DNA was stained with ethidium bromide; the COMET-images were visualized and captured by Olympus fluorescent microscope (BX51; Tokyo, Japan) at 20× magnification equipped with an Olympus CCD camera (12.8 megapixel, DP72; Philippine). 

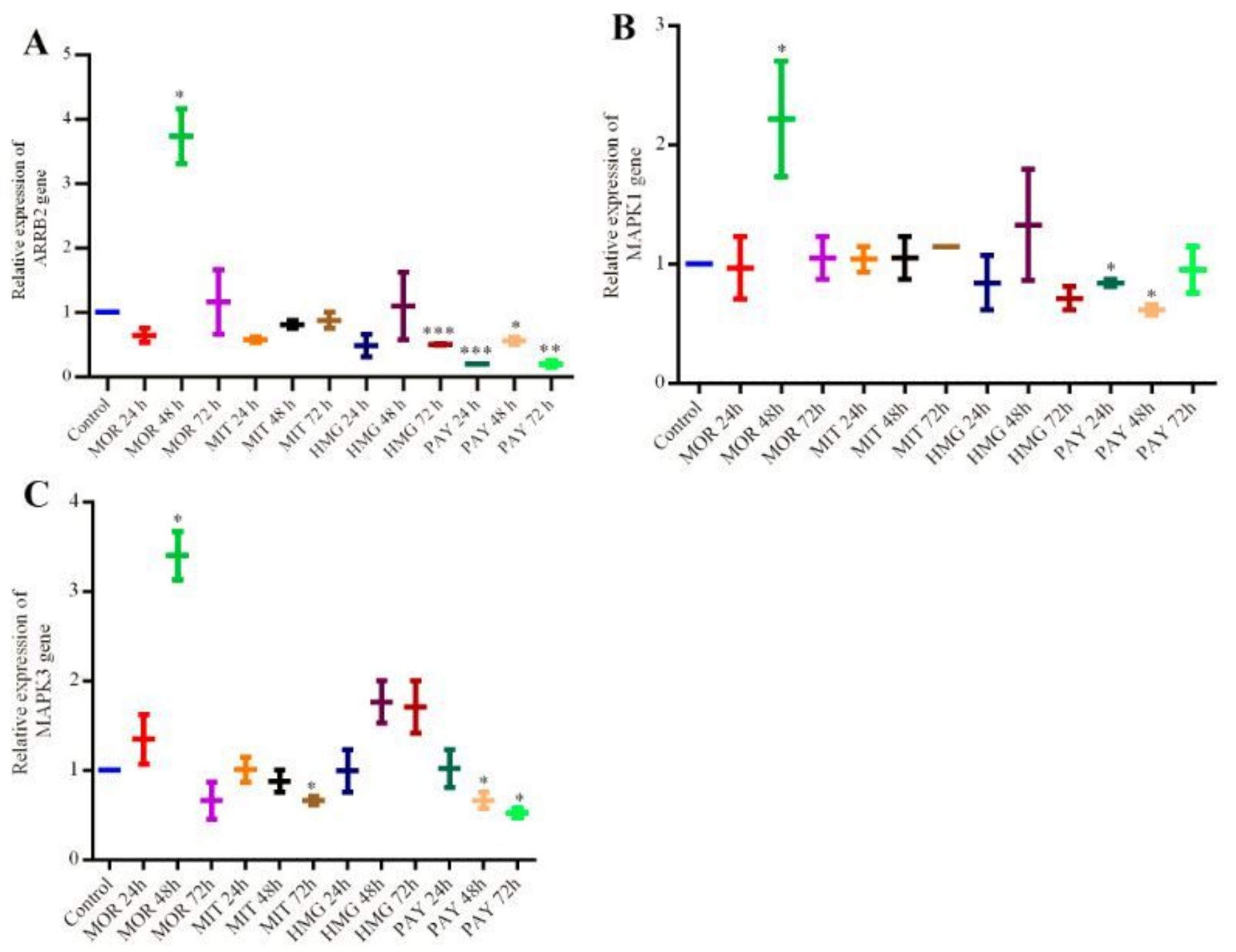

Figure 2

Relative quantification of (A) ARRB2, (B) MAPK1, and (C) MAPK3. SH-SY5Y cells were exposed to IC10 doses of each alkaloid for 24, 48, and $72 \mathrm{~h}$. Quantitative real-time PCR of these transcripts was performed by the Pfaffl method, and $\beta$-actin was appointed as an internal standard normalizer. Results are the mean \pm SD of at least three

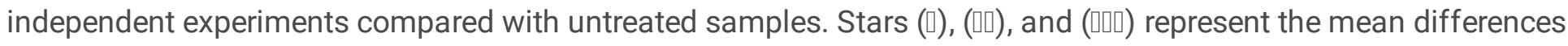
between treated and untreated cell's transcription as $P<0.05, P<0.01$, and $P<0.001$ using one-way ANOVA, respectively. MOR: Morphine, MIT: Mitragynine, HMG: 7-Hydroxymitragynine, and PAY: Paynantheine. 

A Morphine

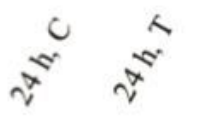
$x^{\infty} x^{\infty} \hat{n}^{\infty} \hat{n}^{\infty}$
B Mitragynine

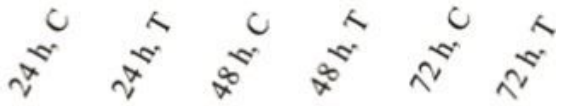
p-ERK1/2,44 kDa
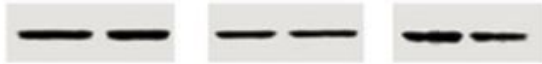
p-ERK1/2,44 kDa
ERK1/2, $42 \mathrm{kDa}$

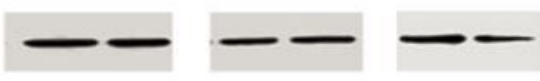
ERK1/2, $42 \mathrm{kDa}$
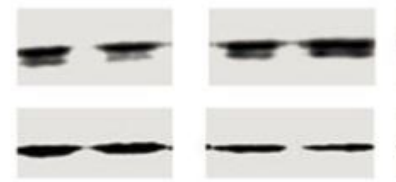
$\beta$-Arrestin, $50 \mathrm{kDa}$
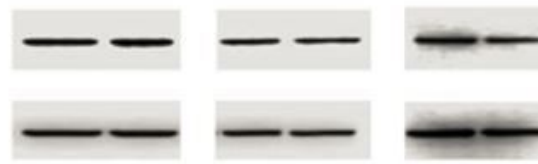
$\beta$-Arrestin, $50 \mathrm{kDa}$
$\beta$-actin, $45 \mathrm{kDa}$

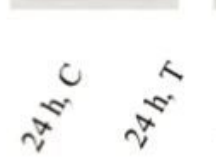
$\beta$-actin, $45 \mathrm{kDa}$

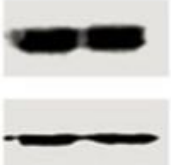
C 7-Hydroxymitragynine

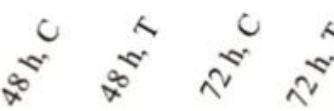
D Paynantheine
p-ERK1/2,44 kDa
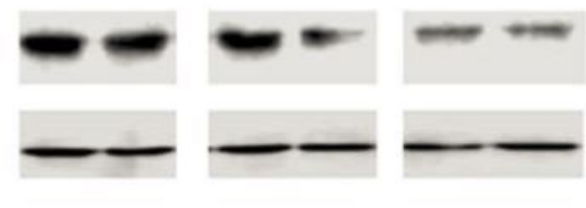
ERK1/2, $42 \mathrm{kDa}$
$\beta$-Arrestin, $50 \mathrm{kDa}$
$\beta$-actin, $45 \mathrm{kDa}$
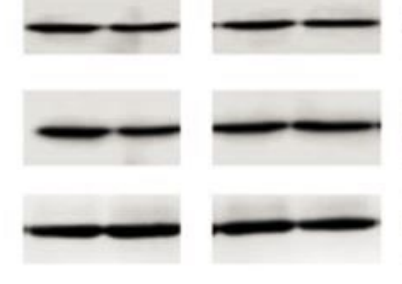
p-ERK1/2,44 kDa
ERK1/2, $42 \mathrm{kDa}$
$\beta$-Arrestin, $50 \mathrm{kDa}$
$\beta$-actin, $45 \mathrm{kDa}$
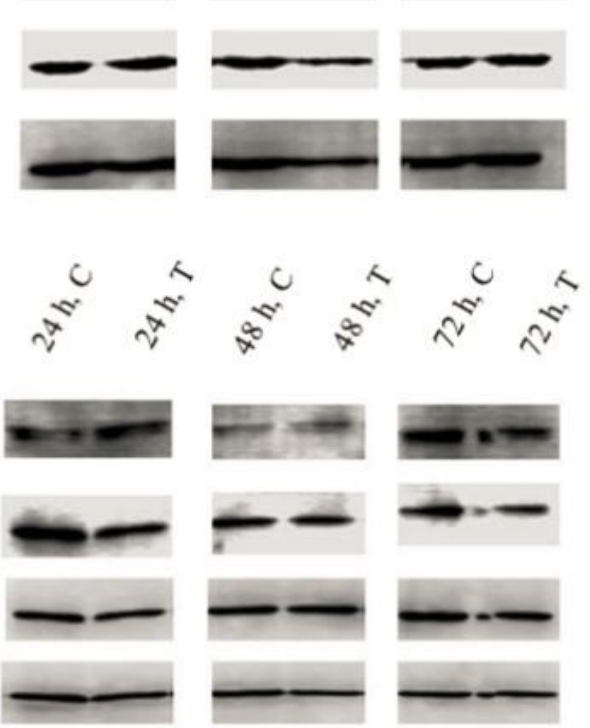

\section{Figure 3}

Western blot analysis of $\beta$-arrestin-2, ERK1/2, and p-ERK1/2 protein. SH-SY5Y cells were treated with morphine (A), mitragynine (B), 7-hydroxymitragynine (C), and paynantheine (D) for 24,48 , or $72 \mathrm{~h}$. Images were recorded using a Li-Cor chemluminescence scanner (letters $\mathrm{C}$ and $\mathrm{T}$ represent Control group and Treatment group, respectively).

\section{Supplementary Files}

This is a list of supplementary files associated with this preprint. Click to download.

- Authoragreementandfinantialinterest.pdf

- Authoragreementandfinantialinterest.pdf

- Authoragreementandfinantialinterest.pdf

- Supplementary74.pdf

- Supplementary74.pdf

- Supplementary74.pdf 